\title{
Ethnoichthyology of fishermen community from the Praia da Penha, in João Pessoa City, Paraíba, Brazil
}

\section{Dyego Medeiros de Almeida ${ }^{1}$, Érica Caldas Silva-Oliveira ${ }^{2, *}$ and Rômulo Romeu Nóbrega Alves ${ }^{2}$}

${ }^{1}$ Universidade Estadual da Paraíba, Conselho de Ensino, Pesquisa e Extensão, Rua Conselheiro José Braz do Rego (Lto. Quadra Mares II), Portal do Sol, João Pessoa, PB, Brazil. E-mail: dygoalmeida@gmail.com

${ }^{2}$ Universidade Estadual da Paraíba, Departamento de Biologia, Rua Baraúnas, 351, Bairro Universitário, CEP 58429-500 Campina Grande, PB, Brazil. *E-mail: erica.caldas71@gmail.com

\begin{abstract}
The interaction of human populations with natural resources mainly related to the perception of the knowledge and the various uses of these resources are the basis for ethnoecological knowledge. The addresses of this research are based on folk knowledge of artisanal fishers of the community of Praia da Penha, in João Pessoa City, Paraíba, Brazil, in order to analyze, through an exploratory case study, the knowledge of ichthyological community is investigated by performing a detailed description qualiquantitatively. Artisanal male fishers, older than 18 years old were interviewed. The results showed that $95 \%$ of the fishermen produce artisanal fishing activities in the community, the average of their age are around 48.2 years old and they represent the economic mainstay in their families and strong family ties reinforce the core traditions of local fishing. The main methods of capturing cited by respondents were handline fishing and the sunk fixed gillnets. Of 192 folk species mentioned, 19 are considered relevant to the community, especially yellowtail snapper (Lutjanus analis), largetooth sawfish (Scomberomorus brasilliensis), king mackerel (Scomberomorus cavalla), common dolphin (Coryphaena hippurus), redfish (Lutjanus purpureus), tuna (Thunnus spp.), smalltooth weakfish (Cynoscion leiarchus), commom halfbeak (Hyporhamphus unifasciatus), Atlantic thread herring (Opisthonema oglinum), triggerfish (Balistes capriscus) and garfish (Strongylura marina). This research reveals that the community of artisanal fishers from Praia da Penha has an extensive ichthyological knowledge, not yet explored in its full possibilities.
\end{abstract}

Keywords: fishing resources, feeding behavior, Brazilian fishermen.

\section{Introduction}

Along the Brazilian coastline, artisanal fishing is one of the most important economic activities, and a direct correlation can be established with the environment and the extraction of natural resources. In Brazilian scenario artisanal
Received

April 21, 2014

Accepted

November 4, 2014

Released

December 31, 2014

Open Acess Full Text Article 
The protein derived from fish is constituted as protein base $(50 \%$ to $68 \%)$ of the diet of residents along the coast of Brazil (Begossi et al., 2000).

Research conducted in recent years indicates that human communities directly dependent on natural resources demonstrates significant knowledge about the environment in which they reside, including the biology and ecology of plants and animals (Gadgil et al., 1993; Berkes, 1999; Diamond, 2005). This knowledge in general is passed from generation to generation. And may be adaptive, since it constitutes the intellectual antecedent of strategies and survival techniques employed by the community over time, in order to ensure continuity and adjusting to the environment (Berkes, 2000; Diegues, 2001). Thus, a culture incorporates all the popular classifications and characteristics of its society, i.e. all ethnoscience of the society, their particular ways of classifying both your material and social universes (Alves, 2005; Alves and Rosa, 2013).

Scientific studies of artisanal fishermen may also contribute to improvement of fishing activity, through the investigation of local knowledge, including the emergence of new information from biology of species, and identify aspects of organization of local populations in the exploration of natural resources, which might be covered in effective management for fishery resources, in effect guaranteeing the survival of populations of artisanal fishermen (Begossi, 2004; Lima-Silva, 2007).

Considering this approach, there is a need for further research aimed at understanding the cognitive aspects of fishermen, since they are in possession of a vast knowledge of the universe of fishing in a particular region. Thus, the fishing community of Praia da Penha, located in João Pessoa City, Paraíba State, Northeast of Brazil, is part of this universe, according to the core, in this community there are many fishermen who hold cognitive characteristics, about the ecology and uses of fish captured, generating an indispensable academic knowledge.

Thus, this work has the purpose to analyze the traditional knowledge of artisanal fishermen from Praia da Penha with respect to the local community ichthyology, seeking to build a detailed view of the universe ichthyological community that can support future investigations of this topic.

\section{Material and Methods}

The study was conducted in fishing community of the Praia da Penha (7॰ 09' 54" S, 34 47' 52" W), located in João Pessoa City (Figure 1). At the time, the local population consisted of artisanal fishermen and formal and informal traders. Praia da Penha has approximately 775 inhabitants, this number changes in summer due to the high demand for vacation homes on site (Silva and Andrade, 2010).

The colony of fishermen from Praia da Penha consists of 60 families, which are distributed in three sets in the neighborhood: The Vila dos Pescadores (Fisherman's Village), the Praça Oswaldo Pessoa (Oswaldo Pessoa Square) and the crowded seaside (Silva and Andrade, 2010). On this beach, are observed beautiful landscapes, and an architectural core religious of the community, scenario of one of the largest secular-religious events of coast of Paraíba (the procession of Nossa Senhora da Penha). The sample comprised 20 artisanal fishermen selected by successive indication of natives who were interviewed.

Data collection occurred between January to July of 2013, using a semistructured questionnaire with oral guided completion, allowing the researcher the monitorization of the steps for completing the instrument adopted (Barbosa, 2010). The interviews were conducted at points of fish landings or in situations where the fishermen were producing-related activities, such as fishing, for example, cleaning and repairing of networks or in their own homes, where permitted and scheduled.

People interviewed were male, over the age of 18 years old, using as criteria for choosing the residence of then in the community, having been a professional fisherman, and not belonging to vulnerable group (older than 60 years old). In addition to these criteria, we selected really competent individuals in the art of artisanal fisheries, a key informant, i.e. a born locally 


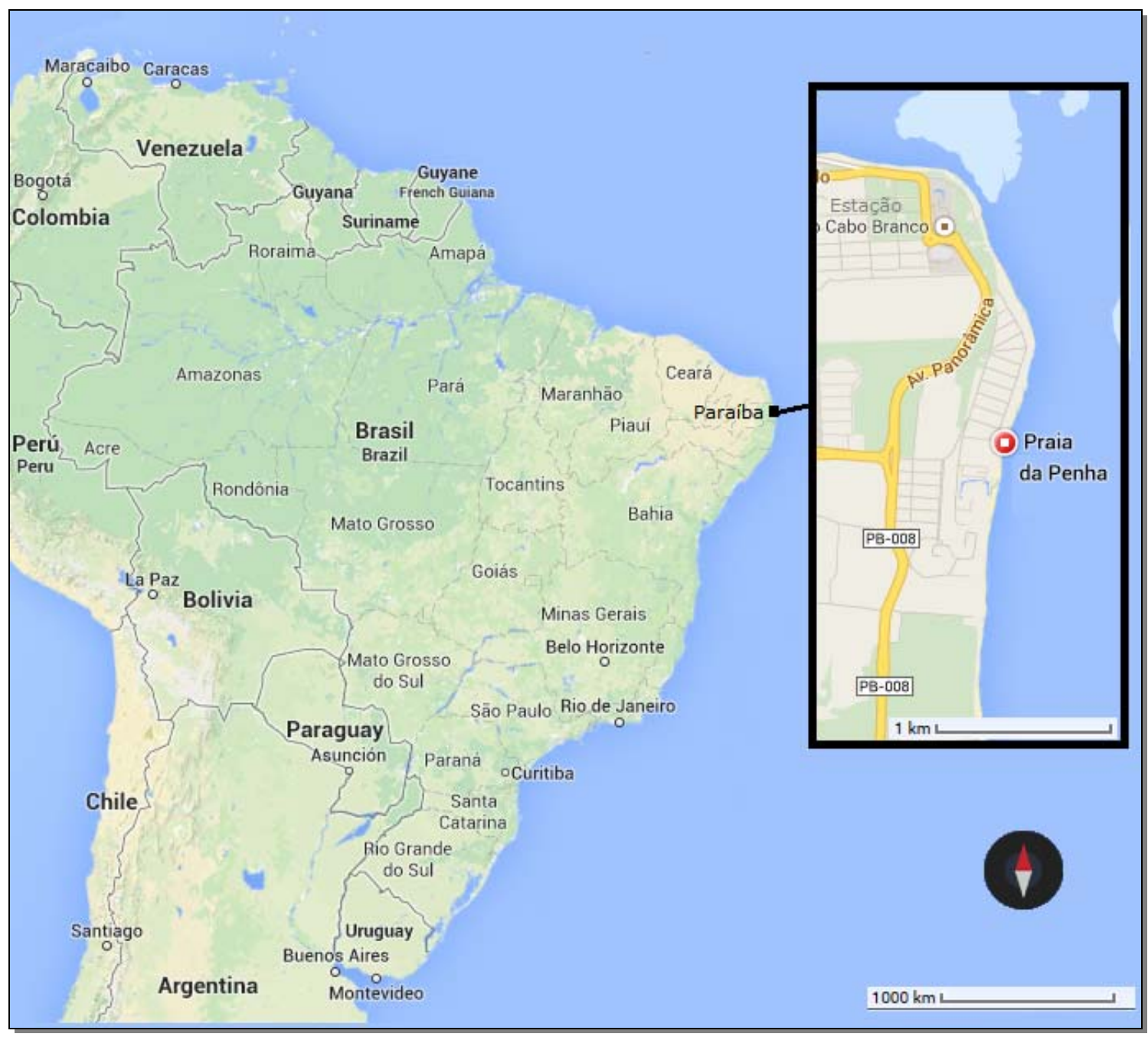

Figure 1. Map of Brazil including the areas and the community studied in Praia da Penha, João Pessoa, Paraíba, Brazil. Adapted from Google Maps.

recognized expert for his skill in the practice of artisanal fishing (Alves et al., 2012).

In a better way of conducting the research, the following steps were adopted: (a) identification of perception of fishermen regarding the sociocultural practice of artisanal fishing in Praia da Penha, with the focus of knowing the motivations and barriers in the practice of artisanal fisheries; (b) survey of the species of known and caught fish in the region, and their equipment used for fishing, cataloging the known species of fish and those caught in the region, (c) and species used in the kitchen and folk medicine.

The folk names of the fish were taxonomically identified by the specific literature (Rocha et al., 1998; Lessa and Nóbrega, 2000; Melo et al., 2002, Sampaio and Nottingham, 2008), with aids of Skaphandrus and Fishbase websites.

\section{Results and Discussion}

\section{Socioeconomic profile}

The average of 48.2 years old was got in this survey with artisanal fishers, that represent the economic mainstay of your household, is dedicated to the fishing activity completely or partially. The average number of family members is about 3.75 people, which is considered a standard number to similar communities, and the time of residence of these families in the community has an average of 42 years old, reinforcing the family roots of fishing activity in the nucleus investigated. There is a correlation between the average lifespan of the respondents with the time they that

Braz. J. Biol. Sci., 2014, v. 1, n. 2, p. 39-49. 
reside in the area was which observed, making it possible to assert that they all began a fishing activity even in youth. Most respondents present basic education (elementary and middle school, 60\%), and $20 \%$ were illiterate. In general, there are similarities between the results of this investigation with the academic research of Oliveira et al. (2010) with the same community of artisanal fishermen, who obtained such results for the primary and secondary values in the order of $65 \%$.

As regards the origin of the practice of fishing, most of the fishermen revealed that they started in fishing activity by family influences and others have pointed out other sources. These results show that the family roots of this economic activity is characterized as a reality for this community, which has grown and continues until the present day by the traditions of fishing on site. Other origins for the practice of fishing were the influence of friends, curiosity, and the need to pursue an economic activity to fund their expenses.

All respondents recognized the fishing activity as one of the most ancient activities in the community, they also realized that in recent years there is a drop in the interest of fishing activity and pointed out some key factors to the decrease in interest in fishing, economic, social and ecological factors. In the economic field, due to the decrease of the amount of fish that reduces consequently the profits from fishing. In the social field, due to population growth and new economic possibilities in the community's neighborhood that is very close to the downtown located in João Pessoa. And in the ecological field, by the scarcity of fishes caused by environmental degradation. Allied to this fact, there is an overall perception that younger people do not manifest more interest as before by artisanal fisheries. According to the elders of the community this lack of interest is given by the self will of the young natives, and the low financial return of the fishing activity, this last statement is considered the decisive factor for the loss of traditional fishing culture among young people.

\section{Local etnoichthyology (known and fished species and capture methods)}

Artisanal fishers recognized 192 folks species present in the region (Table 1), where 72 are identified as preferred for fishing, both for economic reasons and by dietary factors (Table 2).

From this universe of fish, mullet (Mugil spp.), Atlantic thread herring (Opisthonema oglinum), cro-cro grunt (Conodon nobilis), French angelfish (Pomacanthus paru), catfish (Ariidae), shark (Rhizoprionodon lalandii), largehead hairtail (Trichiurus lepturus), silverking (Megalops atlanticus), snook (Centropomus parallelus), soles (Soleidae), trunkfish (Ostraciidae) and Atlantic goliath grouper (Epinephelus itajara) were cited by Mourão and Nordi (2003) in a survey in the Northeast coast of Paraíba.

The main methods of capture indicated by artisanal fishers from Praia da Penha were handline, sunk fixed gillnets, buoyed fixed gillnets, net of sardines, beach seine, traps, harpoon, trawler, hand net and diving. These 10 different capture methods wich were mentioned above, are typically used in the community in the capture of different species of fishs.

The handline is the universal method in the practice of fishing activity in the community. Its applicability achieves greater percentage to catch the 192 species cited in the region. The second most used method is the sunk fixed gillnets. Overall, the most common combination of methods are are sunk fixed gillnets and handline, which shares in the fishing 74 folk species. The values obtained using handline as a kind of method of catching fishes are virtually identical to those recorded by Mariano (2007), with artisanal fishermen on the coast of Paraíba, which has many features in common with the fishermen from Praia da Penha.

Mariano (2007) also emphasizes that handline is preferably used to capture lane snapper (Lutjanus synagris), yellowtail snapper (Lutjanus analis), redfish (Lutjanus purpureus), and largetooth sawfish (Scomberomorus brasilliensis). Besides these folk species, it also confirms that 
Table 1. Fish mentioned by artisanal fishers from Praia da Penha.

\begin{tabular}{|c|c|c|}
\hline English names & $\begin{array}{c}\text { Local folk commum } \\
\text { names }\end{array}$ & Species or taxon \\
\hline Anchovy/Manjuba & Anchova/Manjuba & Engraulidae \\
\hline Arrow barracuda & Bicuda/Barracuda & Sphyraena spp. \\
\hline Atlantic goliath grouper & Mero & Epinephelus itajara (Lichtenstein, 1822) \\
\hline Atlantic moonfish & Galo & Selene setapinnis (Mitchill, 1815) \\
\hline Atlantic thread herring & Sardinha & Opisthonema oglinum (Lesueur, 1818) \\
\hline Balao halfbeak & Agulha-preta & Hemiramphus balao Lesueur, 1821 \\
\hline Barred pargo & Pargo & Lutjanus spp \\
\hline Beard fish & Barbudo & Polydactylus virginicus (Linnaeus, 1758) \\
\hline Black doctorfish & Caraúna & Acanthurus chirurgus (Bloch, 1787) \\
\hline Black drum & Piraúna & Pogonias cromis (Linnaeus, 1766) \\
\hline Black grouper & Serigado & Mycteroperca spp. \\
\hline Butterfish & Bejupirá & Rachycentron canadum (Linnaeus, 1766) \\
\hline Cabezon & Cabeça-dura & Larimus breviceps Cuvier, 1830 \\
\hline Cat shark & Cação-lixa & $\begin{array}{l}\text { Ginglymostoma cirratum } \\
1788 \text { ) }\end{array}$ \\
\hline Catfish & Bagre & Ariidae \\
\hline Chicharro & Chicharro & Carangoides crysos (Mitchill, 1815) \\
\hline Cola & Guaiuba & Ocyurus chrysurus (Bloch, 1791) \\
\hline Commom halfbeak & Agulha & $\begin{array}{l}\text { Hyporhamphus unifasciatus (Ranzani, } \\
\text { 1842) }\end{array}$ \\
\hline Common dolphin & Dourado & Coryphaena hippurus Linnaeus, 1758 \\
\hline Common snook & Robalo & Centropomus undecimalis (Bloch, 1792) \\
\hline Cottonwick grunt & Xira & Haemulon melanurum (Linnaeus, 1758) \\
\hline Cro-cro grunt & Coró & Conodon nobilis (Linnaeus, 1758) \\
\hline Dog snapper & Baúna & Lutjanus jocu (Bloch \& Schneider, 1801) \\
\hline French angelfish & Paru & Pomacanthus paru (Bloch, 1787) \\
\hline Garfish & Agulhão & Strongylura marina (Walbaum, 1792) \\
\hline Glasseye snapper & Olho de vidro & $\begin{array}{l}\text { Heteropriacanthus cruentatus (Lacépède, } \\
\text { 1801) }\end{array}$ \\
\hline Guitarfish & Viola & Rhinobatos percellens (Walbaum, 1792) \\
\hline Horse-eye jack & Xaréu & Caranx latus Agassiz, 1831 \\
\hline Indo-Pacific sailfish & Agulhão de vela & Istiophorus albicans (Latreille, 1804) \\
\hline King Mackerel & Cavala & Scomberomorus cavalla (Cuvier, 1829) \\
\hline Ladyfish & Ubarana & Elops saurus Linnaeus, 1776 \\
\hline Lalau & Piramutaba & $\begin{array}{l}\text { Brachyplatystoma vaillantii (Valenciennes, } \\
1840 \text { ) }\end{array}$ \\
\hline Lane snapper & Ariacó & Lutjanus synagris (Linnaeus, 1758) \\
\hline Largehead hairtail & Espada & Trichiurus lepturus Linnaeus, 1758 \\
\hline Largetooth sawfish & Serra & $\begin{array}{ll}\text { Scomberomorus brasilliensis } & \text { Collette, } \\
\text { Russo \& Zavala-Camin, } 1978 & \\
\end{array}$ \\
\hline Lascar & Macaça & Pegusa lascaris (Risso, 1810) \\
\hline Lippe & Pirambu & Anisotremus surinamensis (Bloch, 1791) \\
\hline Little tunny & Bonito & Euthynnus alletteratus (Rafinesque, 1810) \\
\hline Lookdown & Galo do alto & Selene vomer (Linnaeus, 1758) \\
\hline Mangrove snapper & Cururupa & Micropogonias furnieri (Desmarest, 1823) \\
\hline Moray & Moreia & Gymnothorax funebris Ranzani, 1840 \\
\hline Mullet & Tainha & Mugil spp. \\
\hline Ocean salmon & Peixe-rei & $\begin{array}{l}\text { Elagatis bipinnulata (Quoy \& Gaimard, } \\
\text { 1825) }\end{array}$ \\
\hline Parrotfish & Budião & Sparisoma spp. \\
\hline Permit fish & Pampo & Trachinotus spp. \\
\hline Porkfish & Mercador & Anisotremus virginicus (Linnaeus, 1758) \\
\hline Ray & Arraia & Batoidea \\
\hline
\end{tabular}

Braz. J. Biol. Sci., 2014, v. 1, n. 2, p. 39-49. 
Table 1. (continued).

\begin{tabular}{|c|c|c|}
\hline English names & $\begin{array}{l}\text { Local folk commum } \\
\text { names }\end{array}$ & Species or taxon \\
\hline Red goatfish & Saramunete & Pseudupeneus maculatus (Bloch, 1793) \\
\hline Red grouper & Garoupa & Epinephelus spp \\
\hline Redfish & Dentão & Lutjanus purpureus (Poey, 1875) \\
\hline Redmouth grunt & Cambuba & Haemulon flavolineatum (Desmarest, 1823) \\
\hline Rock hind & Peixe-gato & Ariidae \\
\hline Rooter & Pilombeta & $\begin{array}{l}\text { Chloroscombrus chrysurus (Linnaeus, } \\
\text { 1766) }\end{array}$ \\
\hline Roundhead conga & Pianema & Myripristis jacobus Cuvier, 1829 \\
\hline Runner & Arabaiana & $\begin{array}{l}\text { Elagatis bipinnulata (Quoy \& Gaimard, } \\
\text { 1825) }\end{array}$ \\
\hline Shark & Cação & $\begin{array}{l}\text { Rhizoprionodon lalandii (Müller \& Henle, } \\
\text { 1839) }\end{array}$ \\
\hline Silverking & Camurupim & Megalops atlanticus Valenciennes, 1847 \\
\hline Smalltooth weakfish & Pescada & Cynoscion leiarchus (Cuvier, 1830) \\
\hline Snook & Camurim & Centropomus parallelus Poey, 1860 \\
\hline Soles & Soia & Soleidae \\
\hline Southern kingcroaker & Judeu & Menticirrhus americanus (Linnaeus, 1758) \\
\hline Squid & Lula & Cephalopoda \\
\hline Striped weakfish & Pescada-branca & Cynoscion striatus (Cuvier, 1829) \\
\hline Timuco & Agulhão-roliço & Strongylura timucu (Walbaum, 1792) \\
\hline Tomtate grunt & Sapuruna & Haemulon aurolineatum Cuvier, 1830 \\
\hline Triggerfish & Cangulo & Balistes capriscus Gmelin, 1789 \\
\hline Trunkfish & Baiacu & Ostraciidae \\
\hline Tuna/Albacore & Atum/Albacora & Thunnus spp. \\
\hline Wahoo & Cavala-aimpim & Acanthocybium solandri (Cuvier, 1831) \\
\hline Welchman & Mariquita & Holocentrus adscensionis (Osbeck, 1765) \\
\hline White bashaw & Pescada-amarela & Cynoscion acoupa (Lacepède, 1801) \\
\hline White grunt & Abiquara & Haemulon plumieri (Lacépède, 1801) \\
\hline Whiting & Pirá & Malacanthus plumieri (Bloch, 1786) \\
\hline Wireback & Canguito & $\begin{array}{l}\text { Trachinotus goodei Jordan \& Evermann, } \\
1896\end{array}$ \\
\hline Yellow drum & Boca-mole & Stellifer rastrifer (Jordan, 1889) \\
\hline Yellow jack & Guarajuba & Carangoides bartholomaei Cuvier, 1833 \\
\hline Yellowtail snapper & Cioba & Lutjanus analis (Cuvier, 1828) \\
\hline
\end{tabular}

handline is used to fishing common dolphin (Coryphaena hippurus), arrow barracuda (Sphyraena spp.) and several species of sharks, especially using the technique of the trolling using live baits of mullet (Mugil spp.) or Atlantic thread herring (Opisthonema oglinum).

The use of traps in this community is higher than the average recorded by Mariano (2007). Checking the results of capturing by the methods of network (sunk fixed gillnets, buoyed fixed gillnets, beach seine, mullet gill net and sardine net) shown in study of Mariano (2007) with the indices recorded data of the artisanal fishers from Praia da Penha, it seems like that community uses this gear in smaller quantities.

The 19 species most frequently mentioned by fishermen are also the most desirable in food which typically have better resale value in the fish market in the region. The folk species yellowtail snapper (Lutjanus analis), largetooth sawfish (Scomberomorus brasilliensis), king mackerel (Scomberomorus cavalla), common dolphin (Coryphaena hippurus), redfish (Lutjanus purpureus), tuna (Thunnus spp.), smalltooth weakfish (Cynoscion leiarchus), Atlantic thread herring (Opisthonema oglinum), triggerfish 
Table 2. Preferred species for fishing by artisanal fishermen from Praia da Penha.

\begin{tabular}{|l|c|}
\hline Folk species & $\mathbf{\%}$ \\
\hline Yellow jack and yellowtail snapper & $95 \%$ \\
\hline Largetooth sawfish & $80 \%$ \\
\hline King mackerel & $65 \%$ \\
\hline Lane snapper & $60 \%$ \\
\hline Chicharro and common dolphin & $50 \%$ \\
\hline Redfish, tuna/albacore and runner & $45 \%$ \\
\hline Red grouper and smalltooth weakfish & $40 \%$ \\
\hline Atlantic thread herring and cola & $35 \%$ \\
\hline Lookdown and black grouper & $30 \%$ \\
\hline Cottonwick grunt, welchman and catfish & $25 \%$ \\
\hline Barred pargo, mullet, triggerfish, white grunt, shark, redmouth grunt, permit fish and lippe & $20 \%$ \\
\hline $\begin{array}{l}\text { Arrow barracuda, yellow drum, horse-eye jack, ocean salmon, tomtate grunt, red goatfish } \\
\text { and commom halfbeak }\end{array}$ & $15 \%$ \\
\hline Little tunny, common snook, french angelfish, garfish, Southern kingcroaker and beard fish & $10 \%$ \\
\hline $\begin{array}{l}\text { Indo-Pacific sailfish, rooter, lascar, ladyfish, roundhead conga, Atlantic moonfish, striped } \\
\text { weakfish, white bashaw, largehead hairtail, butterfish, wahoo, whiting, black drum, dog } \\
\text { snapper, timuco, parrotfish, glasseye snapper, rock hind, guitarfish, lalau, snook, porkfish, } \\
\text { wireback, balao halfbeak, cabezon, anchovy/manjuba, mangrove snapper, black doctorfish, } \\
\text { ray and cat shark }\end{array}$ & $5 \%$ \\
\hline
\end{tabular}

(Balistes capriscus), commom halfbeak (Hyporhamphus unifasciatus) and garfish (Strongylura marina) were the most common. Most prominent species listed in Table 2, with higher percentages to yellow jack (Carangoides bartholomaei), yellowtail snapper (Lutjanus analis) and largetooth sawfish (Scomberomorus brasilliensis) are probably items in the menus of local restaurants and bars, and are much desired species in the fish market.

\section{Food and zootherapic uses}

Traditional communities, which are those with a strong tradition which was built by its localculture typically rely on treatment practices and habits obtained from the flora and fauna of its surroundings. Incidentally, an ethnoichthyologic research can find out how fish is used in curing some diseases.

More than that, in communities of artisanal fishermen is very common both as medicinal food use of fish caught. Undeniably, the contribution of many species in enrichment of diet of many families engaged in fishing in the same way that applies in the cure of some diseases. What is missing, however, is properly measured in the impact that this practice has to the artisanal fishers from Praia da Penha.

Regarding to food and zootherapic uses, fishermen were asked about species which are used as food, preferred species, and species little appreciated in food, and those species which are known in the community as "remosas" (harmful), and finally asked about what kind of species are species are used in the process of healing in the community.

Only $10 \%$ of the fish caught are used for food, while $90 \%$ are for sale in the local fish market, which reinforces the essential character of the activity of artisanal fishing at Praia da Penha, where the fishery product is destined to the economic survival of fishermen and in the background the fish which is used as food based family of fishermen.

At the Praia da Penha, 75\% of fishermen prefer the intake of fish as food to the detriment of other protein sources derived from meat, $15 \%$ reported consuming more red meat, and 5\% prefer chicken, other $5 \%$ said no preference. Certainly, the preference for fish has cultural origin. After all, the community has traditions that are followed through centuries by all the residents. 


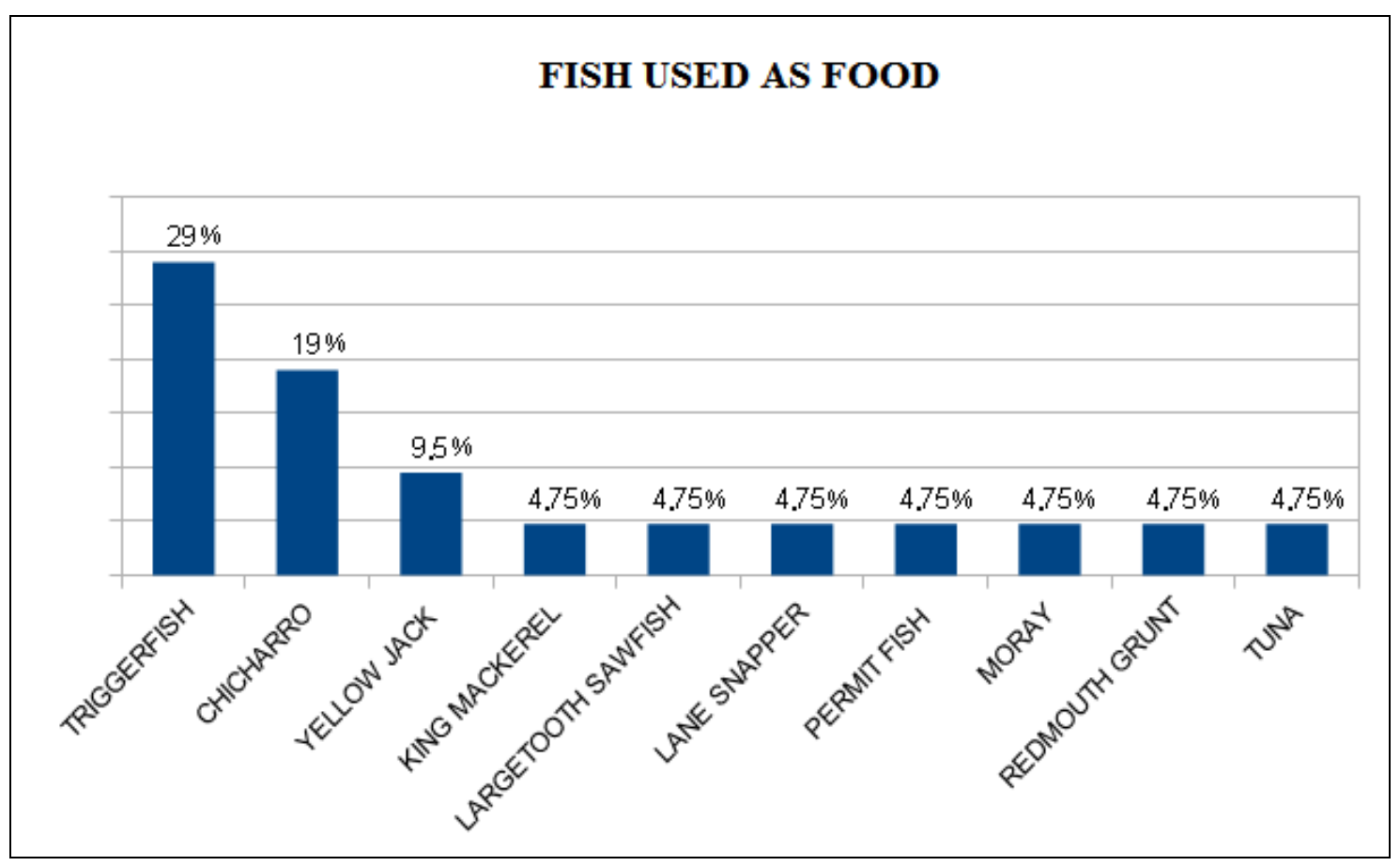

Figure 2. Fish species used as food.

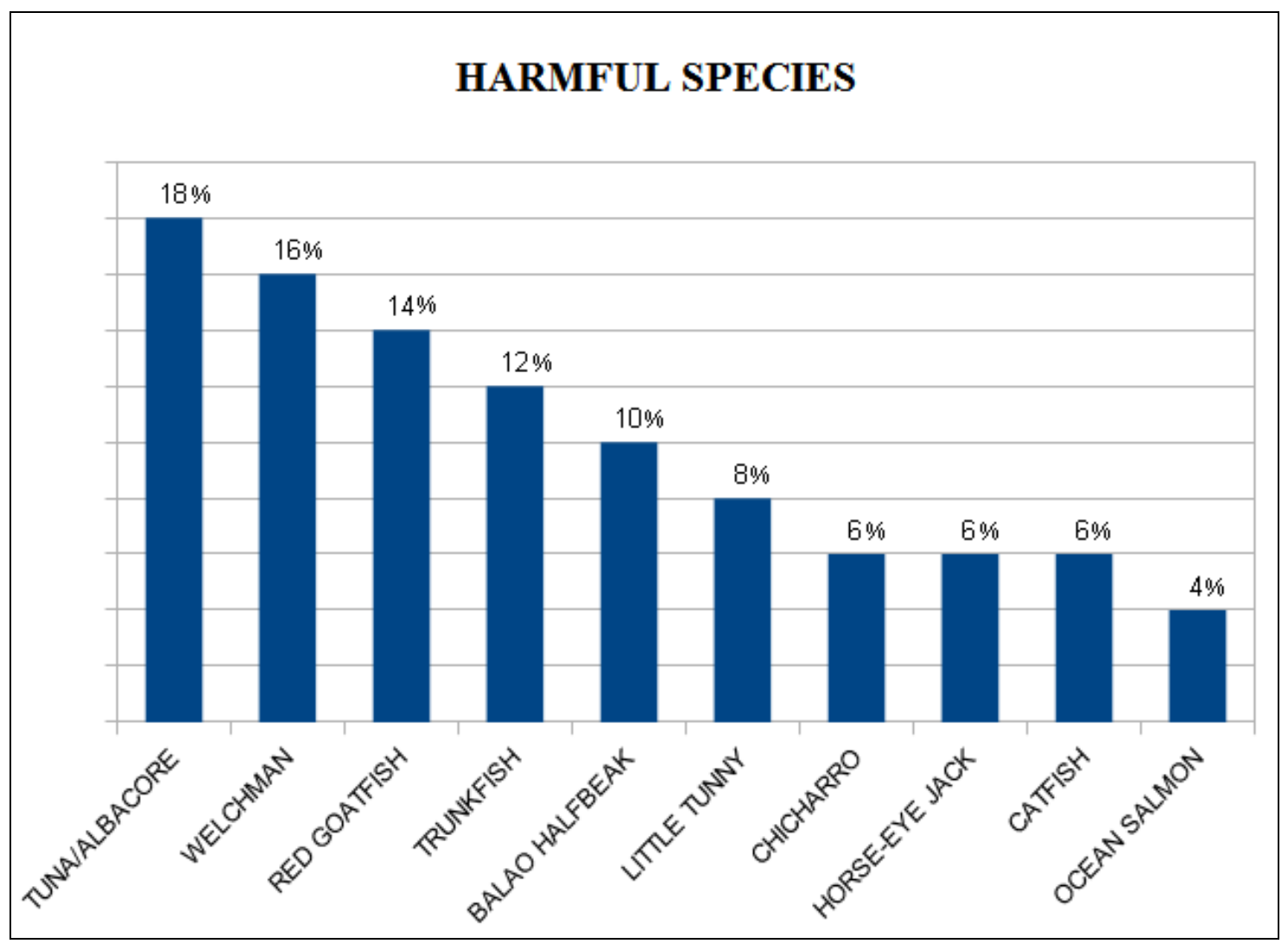

Figure 3. Fish species considered "remosas" (harmful). 


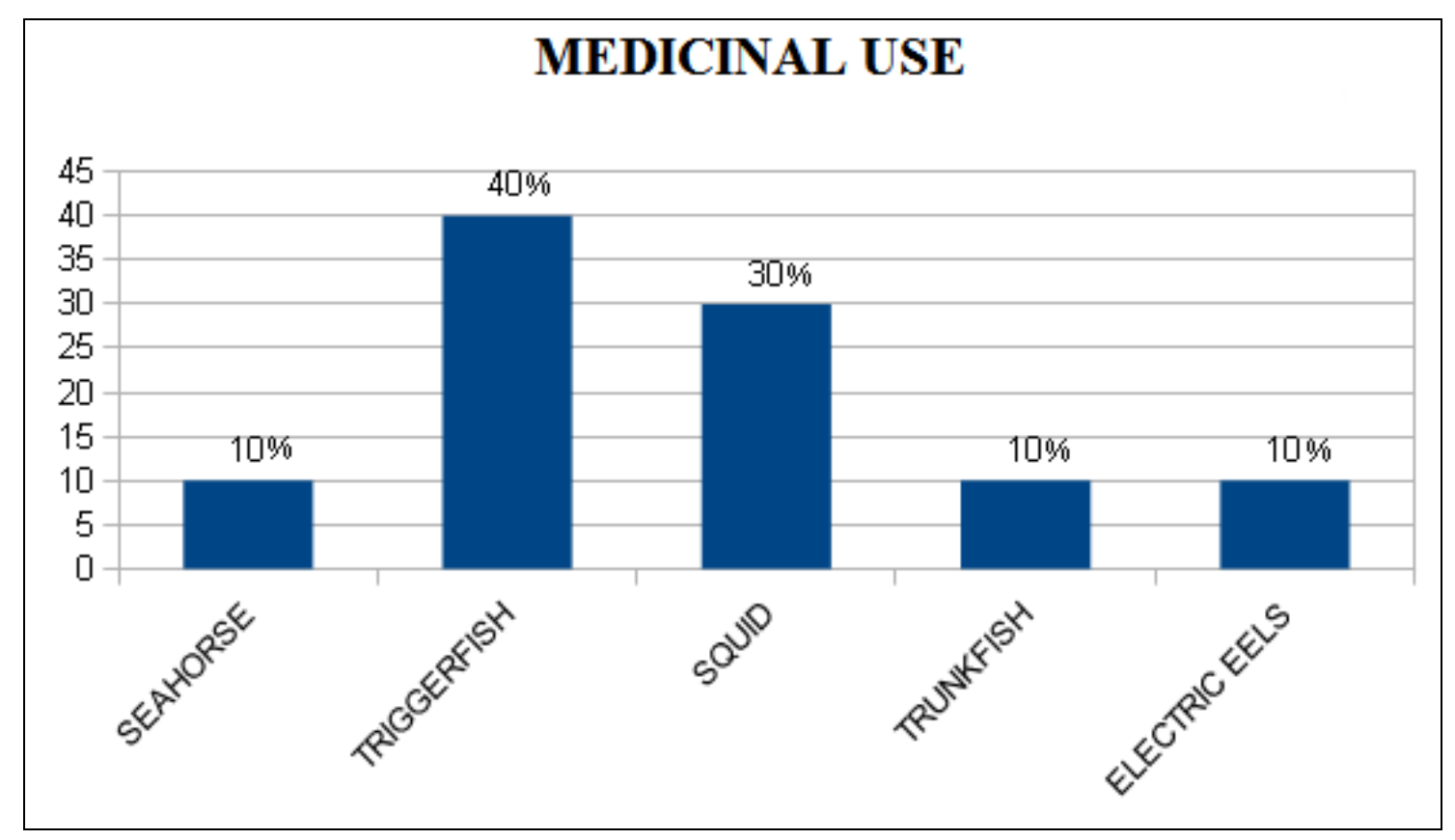

Figura 4. Fish species used in popular medicinal.

The percentage of the most species for food purposes by artisanal fishermen from Praia da Penha is showed in Figure 2.

Fishermen mentioned 11 harmful species (Figure 3). The species that received the highest percentage for this category was tuna (Thunnus spp.), with $18 \%$.

The species considered harmful, just catfish (Ariidae), chicharro (Carangoides crysos) and tuna (Thunnus spp.) are used in feed for fishermen. The chicharro is a fish that has the second highest preference in food.

The discovery of harmful species is an opportunity to learn about the eating habits of the community investigated in relation to food and medicinal potential of the fish. According to Silva (2007), Begossi et al. (2004), and Brito-Júnior and Estácio (2013), among these food taboos, the most important refers to foods considered "remosos" (harmful), an adjective diven to foods that have "reima", i.e., which affect the blood and cause itching.

In the popular culture, "remosos" foods are heavy foods derived from pork; seafood such as crab, shrimp, scaleless fish; and cascudos, such as the tamuata; birds such as ducks; and some wild animals such as lowland pacas and capybaras. These foods should not be eaten by people at risk, for example, postoperative patients and people with infections, inflammations, or injuries, because of the risk of increasing tissue damage, creating pus, and exacerbating the inflammatory process (Costa-Neto, 2000; Begossi et al., 2004; Brito-Júnior and Estácio, 2013).

Besides the traditional use in food, an additional application for some species that are caught in fishing communities with lots of fish, is medicinal. The fishmen interviewed mentioned those fishermen fish species and other taxa, for zootherapic purposes (Figure 4).

The species mentioned for medical use are the triggerfish (Balistes capriscus), for the treatment of ear pain; the squid (Cephalopoda), for the treatment of fatigue, where his gill is extracted and manipulated for oral use; the seahorse (Hippocampus spp.), to improve sexual disposition (aphrodisiac), with infusion preparation for topical use. Ferreira (2013), in addition to these species, mentions that the lizard-fish (Synodus foetens), silverking (Megalops atlanticus), striped weakfish (Cynoscion striatus), white bashaw (Cynoscion acoupa) and grey shark (Carcharhinus limbatus) are used in some regions of Brazil for zootherapic purposes. 


\section{Final considerations}

The community of artisanal fishers from Praia da Penha has its own characteristics, plus a popular knowledge able to offer several discoveries about the fish of the coast of João Pessoa. Given the results presented here, it appears that much can still be discovered, with the help of these fishermen. Data sharing and collaboration among the academic institutions and public organizations could be a solution in bridging fish science and its management (Sharma, 2008).

To the survey of 192 fish species in the region, it was found that 72 species are preferred in fishing due to its commercial value, with the three most sought yellow jack (Carangoides bartholomaei), yellowtail snapper (Lutjanus analis) and largetooth sawfish (Scomberomorus brasilliensis). The food and zootherapic uses, and fishing methods, also will serve as a baseline for future investigations.

According to the fishermen, there is clear reduction of the interest of the younger by the practice of artisanal fishing community. This reduction is the result of the decrease of the fish catch, caused by environmental degradation in recent years. The housing boom and sociocultural changes are key factors that underscore the dynamics of this process in a traditional fishing community.

\section{Acknowledgments}

We thank of the artisanal fishing of the Community of Praia da Penha for participating in the research. We are grateful to André Luiz Machado Pessanha (Departamento de Biologia/UEPB) for his valuable help in identifying the fish species; and we are also very grateful to the two reviewers for their appropriate and constructive suggestions and for their proposed corrections to improve the paper.

\section{References}

Alves, R. R. N.; Rosa, I. L. Toward a plural approach to the study of medicinal animals. In: Alves, R. R. N.; Rosa, I. L. (Eds.). Animals in traditional folk medicine: implications for conservation. Berlin: Springer, 2013. p. 1-9.
Alves, R. R. N.; Rosa, I. L. Why study the use of animal products in traditional medicines? Journal of Ethnobiology and Ethnomedicine, v. 1, p. 1-5, 2005.

Alves， R. R. N; Gonçalves， M. B. R.; Vieira, W. L. S. Caça, uso e conservação de vertebrados no semiárido Brasileiro. Tropical Conservation Science, v. 5, p. 394-416. 2012.

Barbosa, F. A. Descomplicando o complicado: aprendendo a fazer uma monografia em três dias. Rio de Janeiro: Ciência Moderna, 2010.

Begossi, A. Artisanal fisheries in the SE Brazilian coast: using fisher information towards local management. In: Pineda, F. D.; Brebbia, C. A. (Eds). Sustainable Tourism. Southampton: WIT Press, 2004. p. 239-245.

Begossi, A.; Hanazaki, N.; Peroni, N. Knowledge and use of biodiversity in Brazilian hot spots. Environment, Development and Sustainability, v. 2, p. 177-193, 2000.

Begossi, A.; Hanazaki, N.; Ramos, R. M. Food chain and the reasons for fish food taboos among Amazonian and Atlantic Forest fishers (Brazil). Ecological Applications, v. 14, p. 1334-1343, 2004.

Begossi, A.; Silvano, R. A. M.; Amaral, B. D.; Oyakawa, O. T. Uses of fish and game by inhabitants of an extractive reserve (Upper Juruá, Acre, Brazil). Environment, Development and Sustainability, v. 1, 73-93, 1999.

Berkes, F. Sacred Ecology - Traditional Ecological knowledge and Resource Management. Philadelphia: Taylor \& Francis, 1999.

Berkes, F.; Colding, J.; Folke, C. Rediscovery of traditional ecological knowledge as adaptative management. Ecological Applications, v. 10, p. 1251-1262, 2000.

Brito Júnior, L. C.; Estácio, A. G. Food taboos in Medicine: a hypothesis for pathophysiology regarding harmful food. Rev. Assoc. Med. Bras., v. 59, p. 213-216, 2013.

Clauzet, M. Etnoictiologia e uso de recursos naturais por pescadores artesanais costeiros no Brasil. Campinas: Unicamp, 2009. (Doctorat Thesis).

Costa-Neto, E. M. Restrições e preferências alimentares em comunidades de pescadores do Município de Conde, Estado da Bahia, Brasil. Rev. Nutr., v. 13, p. 117-126, 2000.

Costa-Neto, E. M.; Marques, J. G. W. Conhecimento ictiológico tradicional e a distribuição temporal e espacial de recursos pesqueiros pelos pescadores de Conde, Estado da Bahia, Brasil. 
Em Pauta - Revista Etnoecológica, v. 4, p. 5668, 2000.

Diegues, A. C.; Arruda, R. S. V. Saberes tradicionais e biodiversidade no Brasil. Brasília: MMA; São Paulo: USP, 2001.

Ferreira, F. S. Fauna medicinal comercializada no Brasil: Etnozoologia, bioprospecção e conservação. João Pessoa: Universidade Federal da Paraiba/CCEN, 2013. (Doctorat Thesis).

Fishbase. Available from: $<$ http://www.fishbase.org $>$. Accessed in: Aug. 8, 2014.

Gadgil, M.; Berkes, F.; Folke, C. Indigenous knowledge for biodiversity conservation. Ambio, v. 22, p. 151-156, 1993.

Lessa, R.; Nóbrega, M. F. Guia de identificação de peixes marinhos da Região Nordeste. Recife: DIMAR, 2000. (Programa REVIZEE/ SCORE-NE).

Lima-Silva, L. Estudo da viabilidade da produção em cativeiro do peixe ariacó (Lutjanus synagris): proposta de conservação da biodiversidade marinha e de desenvolvimento local para os pescadores da Praia da Penha-PB. João Pessoa: Universidade Federal da Paraíba/Prodema, 2007. (Masters Thesis).

Mariano, E. F. Pesca artesanal na Costa da Paraíba: Procedimentos e capturas da pesca embarcada e aspectos socioeconômicos da população. João Pessoa: Universidade Federal da Paraíba/CE, 2007. (Masters Thesis).

Melo, A. R.; Santos, A. J. G.; Guedes, D. S. Peixes capturados pela pesca artesanal no Litoral Sul da Paraíba (Brasil). Bol. Técn. Cient. CEPENE, v. 10, p. 255-263, 2002.

Mourão, J. S.; Nordi, N. Etnoictiologia de pescadores artesanais do Estuário do Rio Mamanguape Paraíba, Brasil. B. Inst. Pesca, São Paulo, v. 29, p. 9-17, 2003.
Oliveira, P. A.; Vendel, A. L.; Crispim, M. C. B. Caracterização socioeconômica e registro da percepção dos pescadores de lagosta das Praias do Seixas e Penha, João Pessoa, PB. B. Inst. Pesca, v. 35, p. 637-646, 2010.

Rocha, L. A.; Rosa, I. L.; Rosa, R. S. Peixes recifais da Costa da Paraíba, Brasil. Revta. bras. Zool., v. 15, p.553-566, 1998.

Rodrigues, S.C. A pesca artesanal no Município de Cabedelo: entre o desaparecimento e a resistência. João Pessoa: Universidade Federal da Paraíba/CCEN, 2006. (Masters Thesis).

Sampaio, C. L. S.; Nottingham, M. C. Guia para identificação de peixes ornamentais brasileiros: espécies marinhas. Brasília: IBAMA, 2008. v. 1.

Sharma, C. M. Freshwater fishes, fisheries, and habitat prospects of Nepal. Aquatic Ecosystem Health \& Management, v. 11, p. 289-297, 2008.

Silva, A. L. Comida de gente: preferências e tabus alimentares entre os ribeirinhos do Médio Rio Negro (Amazonas, Brasil). Rev. Antropol., v. 50, p. 125-179, 2007.

Silva, L. L; Andrade M. O. Pescadores artesanais da Praia da Penha-PB: novos paradigmas. Revista de Biologia e Ciência da Terra, v.10, p. 105-112, 2010.

Silvano, R. A. M.; Begossi, A. Local knowledge on a cosmopolitan fish. Ethnoecology of Pomatomus saltatrix (Pomatomidae) in Brazil and Australia. Fisheries Research, v. 71, p. 4359, 2004.

Skaphandrus - Sleek, intuitive, and powerful framework, with faster and easier scuba diving data management for sea lovers. Available from: <http://skaphandrus.com>. Accessed in: Aug. 8, 2014.

License information: This is an open-access article distributed under the terms of the Creative Commons Attribution License, which permits unrestricted use, distribution, and reproduction in any medium, provided the original work is properly cited. 